УДК $61: 378: 613.69$.

DOI 10.11603/me.2414-5998.2019.2.10355

Г. О. Данильчук

ORCID 0000-0002-5647-4593

Я. І. Венгер

ORCID 0000-0002-1314-4850

Д. О. Лагода

ORCID 0000-0003-0783-6225

\title{
Одеський національний медичний університет \\ ОЦІНКА СТУПЕНЯ ЕМОЦІЙНОГО ВИГОРАННЯ У ЛІКАРІВ ТА ЛІКАРІВ-ІНТЕРНІВ НА ЕТАПІ ПІСЛЯДИПЛОМНОЇ ОСВІТИ
}

\author{
G. O. Danylchuk, Y. I. Venher, D. O. Lahoda \\ Odesa National Medical University

\section{EVALUATION OF EMOTIONAL BURNOUT IN DOCTORS AND INTERNS AT THE STAGE OF POSTGRADUATE EDUCATION}

\begin{abstract}
Анотація. На сьогодні відомо, що синдром емоційного вигорання, пов’язаний із професійною діяльністю медика, характеризується емоційним виснаженням та призводить до зниження результативності роботи. Дослідження проводилося на кафедрі сімейної медицини та загальної практики Одеського національного медичного університету. У дослідженні взяли участь 80 лікарів, що мали різний стаж роботи. Всім лікарям було проведено анонімне опитування за анкетою, що була розроблена на кафедрі. Лікарі не мали відмінностей у показниках, окрім показника професійної успішності (ПУ), у лікарів зі стажем роботи були достовірно вищі показники порівняно з групою, у яку увійшли лікарі-інтерни (p<0,01). Поряд із цим було встановлено, що 22 \% лікарів мають субклінічний прояв тривоги та 12 \% мають тривожний розлад. Лікарі чоловічої статі є більш витривалими щодо стресових ситуацій на роботі та емоційного вигорання, це підтверджується достовірно нижчими показниками тривоги, депресії, емоційного виснаження, ніж у лікарів жіночої статі (p<0,001). Аналогічні дані ми маємо щодо лікарів-інтернів хлопців, що мають нижчий рівень тривоги та деперсоналізації (p<0,001). У практичну та теоретичну роботу лікарів необхідно вводити тренінги, що мали б на меті покращити психологічний стан лікарів та допомагали здолати або зменшити емоційне вигорання.
\end{abstract}

Ключові слова: лікарі; лікарі-інтерни; емоційне вигорання; тривога; депресія.

Abstract. Today, it is known that the syndrome of emotional burnout associated with the professional activity of a physician, characterized by emotional exhaustion and leads to a reduction in the effectiveness of the work. The research was conducted at the Department of Family Medicine and General Practice of Odesa National Medical University. According to the design, the study involved 80 doctors who had a different work experience. All doctors conducted an anonymous survey, according to the questionnaire developed at the department. Doctors had no differences in indicators other than the indicator of professional success (PS), doctors, with the work experience were significantly higher than in the group which included interns $(\mathrm{p}<0.01)$. Additionally, it was found that $22 \%$ of doctors have a subclinical manifestation of anxiety and $12 \%$ have anxiety disorder. Male therapists are more resistant to stressful work and emotional burnout, as evidenced by significantly lower rates of anxiety depression, emotional exhaustion than female doctors $(p<0.001)$. We have similar data with regard to male interns with lower levels of anxiety and depersonalization $(p<0.001)$. In practical and theoretical work of doctors it is necessary to introduce trainings aimed at improving the psychological state of doctors and helping to overcome or reduce emotional burnout.

Key words: doctors; intern doctors; emotional burnout; anxiety; depression.

Вступ. У сучасній літературі перші згадки про емоційне вигорання (EB) серед лікарів було описано ще в 1974 р., але це поняття було розмите та важко піддавалося розумінню. На сьогодні відомо, що це синдром, який пов' язаний із професійною діяльністю медика, що характеризується емоційним виснаженням та призводить до зниження результативності роботи [8]. Також однією з характерних рис цього синдрому є цинічне ставлення до (с) Г. О. Данильчук, Я. І. Венгер, Д. О. Лагода повсякденних занять та пов'язане з цим зверхнє ставлення до пацієнта.

Причини виникнення синдрому складні. Залишаються невирішеними шляхи подолання цього кризового стану. Ключове питання полягає в тому, чи робить трудова діяльність людину недієздатною або у неї з самого початку є схильність до емоційного вигорання. Стрес і вигорання можуть бути викликані поєднанням багатьох факторів, серед яких можна виділити такі, як: надмірне робоче наванта- 
ження, надмірні робочі години, скарги пацієнтів і неадекватна адміністративна підтримка.

Існують дані, які свідчать про наявність гендерних відмінностей у стресових ситуаціях, що тривають певний час. У стресових ситуаціях та в епізодах ЕВ чоловіки показують підвищений рівень соматичних симптомів, у той час як жінки показують більше психологічних симптомів. При більш детальному розгляді виявляється, що жертви вигорання можуть вести нездоровий спосіб життя, включаючи надмірне вживання їжі і збільшення споживання алкоголю.

На сьогодні найбільше дослідження щодо проблеми ЕВ серед лікарів було проведено у 2011 р., так, було повідомлено, що у 45 \% 37288 лікарів відмічений як мінімум один із симптом вигорання [4]. Поряд із цим було виявлено, що вигорання було більш поширене серед лікарів, ніж серед працівників інших галузей. Загальним фактором було те, що лікарі у своїй роботі мають постійний тісний контакт із пацієнтом і, мабуть, тому мали більш високі показники ЕВ. Вигорання впливає на лікарів на всіх етапах їх кар’єри, від інтернів до лікарів з багаторічним стажем.

Patricia Casey у своєму дослідженні стверджує, що лікарі найбільше стурбовані якістю управління охороною здоров’я та негативним соціокультурним середовищем [5]. Зміна настрою, що пов’язана 3 EB та депресією (Д), може призвести до того, що лікар буде грубим та неуважним до пацієнта, що, у свою чергу, дратуватиме останнього. Загальні закономірності припускають, що одна третина лікарів буде страждати від вигорання, головна проблема в тому, що з цим робити.

У своїх публікаціях Blanaid Hayes говорить, що психосоціальна небезпека стала основним фактором стресу на робочому місці в наші дні [6]. У більшості людей у роботі є піки і спади, але до лікарів ставлять вищі вимоги.

Багато питань, 3 якими стикаються практичні лікарі кожен день, що не мають під собою суто медичного підгрунтя, впливають на збільшення ЕВ та Д. Збільшення роботи з документами при реєстрації пацієнта є однією з таких проблем для лікарів. Впровадження електронних медичних записів також збільшує тягар повсякденної канцелярської роботи лікаря. Тобто в той час, коли адміністративні обов’язки лікаря збільшуються, секретарської підтримки чекати не доводиться. Одне європейське дослідження показало, що на кожну годину клінічної роботи лікар витрачає 2 год на канцелярську діяльність, серед українських лікарів цих даних немає.
Існує брак часу і відсутність контролю над робочими процесами у медичній галузі. Конфлікти між людьми або між групами людей можуть мати помітні негативні наслідки для професійної діяльності. Вигорання у клініцистів також пов'язане 3 ростом медичних помилок та пов’язаною з цим незадоволеністю пацієнтів. Є дані, що говорять про те, що рівень самогубств серед лікарів у світі удвічі вищий, ніж серед населення в цілому.

На сьогодні мало опубліковано даних щодо того, як боротися з проблемою ЕВ. Одним із можливих кроків може бути зменшення та спрощення кількості документації після найпростіших клінічних зустрічей. Всі майбутні розробки у сфері електронної охорони здоров'я повинні бути перевірені на предмет можливого збільшення адміністративного робочого навантаження клініцистів. Підтримка вимог сертифікації повинна бути краще інтегрована в напружений графік роботи лікаря. Ключове повідомлення полягає в тому, щоб ідентифікувати, скоротити і делегувати канцелярський компонент роботи.

Лікарі, з іншого боку, зобов’язані піклуватися про себе. Три важливих питання для будь-якого лікаря - це адекватний сон, адекватні фізичні вправи та увага до особистих медичних потреб.

National Academy of Medicine провела спільну роботу з більш ніж 20 медичними організаціями для вирішення проблеми стресу на робочому місці [3]. Це може бути використано для вирішення проблем Д та ЕВ серед лікарів. У цій роботі говориться, що благополуччя лікаря має бути головним пріоритетом в обговоренні питань догляду за пацієнтами. Завдання роботи полягає в тому, щоб оцінити і зрозуміти причини вигорання лікаря i запропонувати рішення для вирішення проблеми. Необхідно пам’ятати, що потрібні індивідуальні та організаційні рішення.

West et al. провели мета-аналіз заходів, спрямованих на зменшення вигорання лікарів [7]. Вони опрацювали 2617 статей, з яких у 15 були наведені дані рандомізованих досліджень. Корисними стратегіями вирішення питань Д та ЕВ серед цих досліджень були уважність, управління стресом і обговорення в невеликих групах. Уважність - це практика, що має на меті допомогти лікарю взагалі відчути повну присутність у даний момент у даному місці. Це допомагає людині визначити, як часто вона реагує, а не відповідає формально. Коли своєю директивою ЄС ввела певні обмеження щодо робочого часу, європейські лікарі перестали стикатися з даною проблемою [2]. Однак лікарі, що працюють в Україні, не завжди захищені таким же чином. 
Згадуючи все перераховане вище та відсутність даних щодо ЕВ та Д серед лікарів та інтернів України й Одеського регіону зокрема, $є$ необхідність у проведенні дослідження, тому метою нашого дослідження була оцінка ступеня емоційного вигорання у лікарів і лікарів-інтернів загальної практики та сімейної медицини на етапі післядипломної освіти.

Методи дослідження. Дослідження проводилося на кафедрі сімейної медицини та загальної практики Одеського національного медичного університету. У дослідженні брали участь 80 лікарів, що мали різний стаж роботи та спеціальність «Загальна практика - сімейна медицина» (ЗПСМ) або працювали дільничними терапевтами (ДТ). Всі лікарі були розділені на дві групи: I група лікарі ЗПСМ або ДТ, у яку увійшли 50 чоловік, та II група - 30 лікарів-інтернів, що проходили очне навчання на базі кафедри сімейної медицини та загальної практики за спеціальністю ЗПСМ. Усім лікарям було проведено анонімне опитування за анкетою, що була розроблена на кафедрі та включала такі питання: вік, стать, спеціальність, за якою працював лікар, та стаж роботи. Також до анкети були включені опитувальники для оцінки тривоги (T), депресії (Д) та емоційного вигорання (EB), а саме госпітальна шкала T та Д (HADS) й опитувальник професійного (емоційного) вигорання (MBI) в адаптації Н. Є. Водоп'янової за методикою К. Маслач та С. Джексон [1].

Госпітальна шкала T та Д (HADS) розроблена A. S. Zigmond i R. P. Snaith в 1983 р. для виявлення та оцінки тяжкості депресії і тривоги в умовах загальномедичної практики. Переваги обговорюваної шкали полягають у зручності застосування та обробки, що дозволяє рекомендувати її до використання у практиці для первинного виявлення тривоги і депресії у пацієнтів, а саме скринінгу. Опитувальник має високу дискримінантну валідність щодо двох розладів: тривоги і депресії.

Процедура проведення полягає в тому, що госпітальна шкала тривоги і депресії містить 14 пунктів, кожному з яких відповідають 4 варіанти відповідей, що відображають ступінь наростання симптоматики. Шкала складена з 14 тверджень, які обслуговують 2 підшкали: «Т» (непарні пункти - 1, 3, 5, 7, 9, 11, 13); «Д» (парні пункти - 2, 4, 6, 8, 10, 12, 14).

Кожному із тверджень відповідають 4 варіанти відповіді, що відображають градації ознак та кодуються за збільшенням тяжкості симптому від 0 (відсутність) до 3 (максимальна вираженість).
При інтерпретації результатів враховується сумарний показник по кожній підшкалі, при цьому виділяються 3 області його значень: 0-7 - норма (відсутність достовірно виражених симптомів тривоги і депресії), 8-10 - субклінічно виражена тривога/депресія, 11 і вище - клінічно виражена тривога/депресія.

Опитувальник «Професійне (емоційне) вигорання» розробили на основі трифакторної моделі К. Маслач і С. Джексон й адаптували Н. Водоп'янова, Е. Старченкова. Методика призначена для діагностики «емоційного виснаження», «деперсоналізації» i «професійних досягнень». Тест містить 22 твердження про почуття та переживання, що пов'язані з виконанням робочої діяльності. Про наявність високого рівня вигорання свідчать високі оцінки по таких шкалах, як «емоційне виснаження» та «деперсоналізація» і низькі - за шкалою «професійна ефективність» (редукція персональних досягнень). Відповідно, чим нижче людина оцінює свої можливості і досягнення, менше задоволена самореалізацією в професійній сфері, тим більше виражений синдром вигорання. Діагностуючи вигорання, слід враховувати конкретні значення шкал (факторів), які мають вікові і гендерні особливості.

Розділяють різні варіанти тесту згідно з професійною діяльністю, а саме: для педагогів, вчителів; керівників середньої ланки; співробітників комерційної служби (маркетологів, агентів, менеджерів); продавців роздрібної торгівлі; медичних працівників (лікарів).

Інструкція до використання проста та має такі кроки: 22 твердження про почуття та переживання, пов'язані з роботою, на які відповідно до того, як часто людина відмічає цю проблему, існують шість варіантів відповіді, де 0 - «ніколи», а позиція 6 - «щодня».

При оцінці результатів необхідно враховувати стать опитуваного, від цього буде залежати показник рівня вигорання. Для оцінки результатів необхідно користуватися таблицями, що є у вільному доступі в інтернет-мережі.

Статистичний аналіз проводився за загальноприйнятими методами варіаційної статистики. Достовірність оцінювали за t критерієм Стьюдента. Відмінності визнавались істотними при рівні значущості $\mathrm{p} \leq 0,05$. Кореляційний зв'язок встановлювався за допомогою критерію кореляції Спірмена та кореляційно-регресивний аналіз за Пірсеном.

Результати дослідження. Робота медичних працівників відповідальна, передбачає високе і постій- 
не психоемоційне навантаження, яке в подальшому може перерости в емоційне вигорання на робочому місці. Тож нас зацікавило, чи має таке явище місце в лікарів первинної ланки Одеського регіону.

Вище було вказано, що лікарі були розділені на дві групи. У І групу увійшли лікарі ЗПСМ або ДТ у кількості 50 чоловік. Середній вік лікарів склав $(51,7 \pm 1,83)$ року, з них 14 були чоловіки та 36 жінок. Необхідно відмітити, що 4 лікарі з 50 займали керівні посади, а саме 3 завідувачі амбулаторій та 1 головний лікар центру первинної медико-санітарної допомоги. Серед лікарів були лікарі 3ПСМ (n=25) та ДТ (n=21). При оцінці стажу роботи ми мали середній показник, що склав $(23,26 \pm 1,86)$ року, в той час як найменший стаж роботи склав 3 роки, а найбільший - 46 років.

У II групу увійшли 30 лікарів-інтернів, середній вік яких склав $(25,36 \pm 0,44)$ року, з них 10 були чоловіки та 20 жінок. Всі лікарі-інтерни мали спеці- альність ЗПСМ, середній стаж роботи на первинній ланці у цій групі склав 8 місяців.

У таблиці 1 ми маємо дані щодо опитувальників I та II груп.

У наведеній таблиці видно, що лікарі не мали відмінностей у показниках, окрім показника професійної успішності (ПУ), у лікарів зі стажем роботи були достовірно вищі показники порівняно 3 групою, у яку увійшли лікарі-інтерни $(\mathrm{p}<0,01)$. При аналізі середніх показників Т та Д не було виявлено. Показники емоційного вигорання, а саме емоційне виснаження відповідає високому рівню, у той час як деперсоналізація та професійна успішність відповідають дуже високому рівню.

Такі патологічні стани, як Т або Д, мають різний ступінь перебігу, тому ми вирішили представити не тільки середні показники у всіх групах, а й окремі показники за ступенем прояву проблеми (табл. 2).

Таблиця 1. Результати опитувальників у досліджуваних групах

\begin{tabular}{|l|c|c|c|c|c|}
\hline \multicolumn{1}{|c|}{ Група } & $\begin{array}{c}\text { Тривога } \\
\text { (бали) }\end{array}$ & $\begin{array}{c}\text { Депресія } \\
\text { (бали) }\end{array}$ & $\begin{array}{c}\text { Емоційне } \\
\text { вистаження } \\
\text { (бали) }\end{array}$ & $\begin{array}{c}\text { Деперсоналізація/ } \\
\text { цинізм (бали) }\end{array}$ & $\begin{array}{c}\text { Професійна } \\
\text { успішність } \\
\text { (бали) }\end{array}$ \\
\hline Лікарі & $5,20 \pm 0,42$ & $4,54 \pm 0,37$ & $25,03 \pm 0,82$ & $15,11 \pm 0,47$ & $* 35,97 \pm 0,89$ \\
\hline Лікарі-інтерни & $6,19 \pm 0,67$ & $4,31 \pm 0,51$ & $26,08 \pm 1,18$ & $15,42 \pm 0,62$ & $32,28 \pm 1,13$ \\
\hline
\end{tabular}

Примітка. $\mathrm{p}<0,01$.

Таблиця 2. Ступінь прояву симптомів тривоги та депресії в досліджуваних групах

\begin{tabular}{|l|c|c|c|c|}
\hline \multirow{2}{*}{\multicolumn{1}{|c|}{ Прояв }} & \multicolumn{2}{|c|}{ Лікарі } & \multicolumn{2}{c|}{ Інтерни } \\
\cline { 2 - 5 } & тривога & депресія & тривога & $24(80 \%)$ \\
\hline Норма & $33(66 \%)$ & $44(88 \%)$ & $17(56,6 \%)$ & $6(20 \%)$ \\
\hline Субклінічна & $11(22 \%)$ & $5(10 \%)$ & $12(40 \%)$ & - \\
\hline Клінічна & $6(12 \%)$ & $1(2 \%)$ & $1(3,33 \%)$ & десія \\
\hline
\end{tabular}

У наведеній таблиці видно, що 22 \% лікарів мають субклінічний прояв тривоги та $12 \%$ мають тривожний розлад. Також із цих же лікарів $10 \%$ мають субклінічний депресивний розлад та 1 лікар - клінічний перебіг депресії. У лікарів-інтернів ми мали таку тенденцію: 12 чоловік (40 \%) мали субклінічний перебіг тривожного синдрому та 1 інтерн мав клінічний перебіг. Щодо депресивного розладу, то в жодного лікаря-інтерна не було діагностовано клінічного перебігу та в 20 \% ми мали субклінічний перебіг депресивного синдрому.

При проведенні кореляційного аналізу між професійним стажем та показниками ми мали результати, що представлені у таблиці 3.

Таблиця 3. Кореляційний аналіз між професійним стажем лікарів та досліджуваними показниками

\begin{tabular}{|c|c|c|c|c|c|}
\hline Група & $\begin{array}{c}\text { Тривога } \\
\text { (бали) }\end{array}$ & $\begin{array}{c}\text { Депресія } \\
\text { (бали) }\end{array}$ & $\begin{array}{c}\text { Емоційне висна- } \\
\text { ження } \\
\text { (бали) }\end{array}$ & $\begin{array}{c}\text { Деперсона- } \\
\text { лізація/ } \\
\text { цинізм (бали) }\end{array}$ & $\begin{array}{c}\text { Професійна } \\
\text { успішність } \\
\text { (бали) }\end{array}$ \\
\hline Лікарі & $\mathrm{r}=-0,028$ & $\mathrm{r}=-0,042$ & $\mathrm{r}=-0,200$ & $\mathrm{r}=0,044$ & $\mathrm{r}=0,170$ \\
& $\mathrm{p}=0,86$ & $\mathrm{p}=0,77$ & $\mathrm{p}=0,23$ & $\mathrm{p}=0,31$ \\
\hline
\end{tabular}


У І групі, у яку увійшли лікарі з різним стажем роботи, не було встановлено кореляційного зв'язку між стажем роботи та досліджуваними показниками, а саме тривогою, депресією, емоційним виснаженням, деперсоналізацією та професійною успішністю.

При проведенні статистичних підрахунків ми звернули увагу на те, що дані в чоловіків і жінок відрізняються, тому провели окремий аналіз у цьому напрямку. Більш детальні дані наведено у таблицях 4, 5.
У наведених таблицях видно, що лікарі зі стажем роботи мають достовірно нижчі показники Т, Д, емоційного виснаження та ПУ, ніж лікарі жіночої статі ( $<<0,001)$. Щодо групи II, у яку увійшли лікарі-інтерни, мали аналогічні дані щодо Т, тобто тривожні розлади фіксувались у дівчат-інтернів достовірно частіше, ніж у хлопців $(\mathrm{p}<0,001)$. У лікарів-інтернів чоловічої статі поряд із Т було визначено достовірно нижчий показник деперсоналізації/цинізму та вищий показник ПУ, ніж у лікар-інтернів жіночої статі $(\mathrm{p}<0,001)$.

Таблиця 4. Оцінка результатів госпітальної шкали тривоги та депресії відповідно до статі в досліджуваних групах

\begin{tabular}{|c|c|c|c|}
\hline Група & Стать & Тривога (бали) & Депресія (бали) \\
\hline \multirow{2}{*}{ Лікарі } & чоловіча & $* 3,64 \pm 0,53$ & $* 3,64 \pm 0,42$ \\
\cline { 2 - 4 } & жіноча & $6,67 \pm 0,44$ & $5,53 \pm 0,35$ \\
\hline${ }^{*} \mathrm{p}<0,001$ & $* 4,00 \pm 0,80$ & $3,10 \pm 0,53$ \\
\hline \multirow{2}{*}{ Лікарі-інтерни } & чоловіча & $7,25 \pm 0,67$ & $4,70 \pm 0,60$ \\
\cline { 2 - 4 } & жіноча & \multicolumn{2}{|c|}{} \\
\hline
\end{tabular}

Таблиця 5. Оцінка результатів опитувальника «Професійне (емоційне) вигорання» відповідно до статі в досліджуваних групах

\begin{tabular}{|c|c|c|c|c|}
\hline Група & Стать & $\begin{array}{c}\text { Емоційне висна- } \\
\text { ження } \\
\text { (бали) }\end{array}$ & $\begin{array}{c}\text { Деперсона- } \\
\text { лізація/ } \\
\text { цинізм (бали) }\end{array}$ & $\begin{array}{c}\text { Професійна } \\
\text { успішність } \\
\text { (бали) }\end{array}$ \\
\hline \multirow[t]{2}{*}{ Лікарі } & чоловіча & $* 21,73 \pm 1,06$ & $14,45 \pm 0,61$ & $* * 33,91 \pm 0,69$ \\
\hline & жіноча & $26,62 \pm 0,94$ & $15,58 \pm 0,61$ & $37,42 \pm 0,98$ \\
\hline \multicolumn{5}{|c|}{${ }^{*} \mathrm{p}<0,001, * * \mathrm{p}<0,05$} \\
\hline \multirow[t]{2}{*}{ Лікарі-інтерни } & чоловіча & $23,10 \pm 1,18$ & $* 13,20 \pm 0,77$ & $* 36,80 \pm 0,81$ \\
\hline & жіноча & $26,85 \pm 1,41$ & $16,05 \pm 0,66$ & $31,95 \pm 1,22$ \\
\hline
\end{tabular}

При аналізі отриманих даних у таблицях 4, 5 ми мали схожі дані в чоловіків та жінок, окрім показника ПУ, тож нами було проведено окремий розрахунок для лікарів-чоловіків та було встановлено, що лікарі-інтерни мали достовірно більш високу кіль-

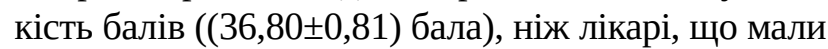
більший стаж роботи ((33,91 $\pm 0,69)$ бала) $(p=0,01)$. На нашу думку, це можна пояснити тим, що молоді лікарі-чоловіки є більш амбітними та цілеспрямованими та, можливо, у своїй нетривалій самостійній роботі ще не стикалися з випадками, що мали вплив на суб’єктивне відчуття професійної успішності.

У приватних бесідах під час проведення навчального процесу лікарі обох груп скаржилися на велике навантаження, стресові ситуації під час роботи та велику кількість роботи з документацією. Лікарі обох груп висловлювали бажання брати участь у тренінгах, що б допомогли позбутися або зменшити емоційне вигорання, тривожні та депресивні стани.

Тож спираючись на все вищезгадане, ми можемо зробити такі висновки та запропонувати перспективи подальших досліджень:

1. Емоціональне вигорання є дуже широкою проблемою, що охоплює багато лікарських спеціальностей, а більш за все лікарів первинної ланки.

2. Рівень тривоги, депресії, емоційного виснаження, деперсоналізації є приблизно однаковим у лікарів з великим стажем роботи та в лікарів-інтернів.

3. Емоційне вигорання не має кореляційного зв’язку зі стажем роботи лікаря.

4. Лікарі чоловічої статі є більш витривалими щодо стресових ситуацій на роботі та емоційного вигорання, це підтверджується достовірно нижчими показниками тривоги, депресії, емоційного 
виснаження, ніж у лікарів жіночої статі ( $<<0,001)$. Аналогічні дані ми маємо щодо лікарів-інтернів хлопців, що мають нижчий рівень тривоги та деперсоналізації ( $<<0,001)$.

5. У лікарів-чоловіків відрізнялися показники професійної успішності, так, у лікарів-інтернів цей показник був достовірно вищий, ніж у лікарів-

\section{Список літератури}

1. Котова Е. В. Профилактика синдрома эмоционального выгорания : учебное пособие [Электронный ресурс] / Е. В. Котова ; Краснояр. гос. пед. ун-т им. В. П. Астафьева. - Красноярск, 2013. - Режим доступа : http:// www.kspu.ru/upload/documents/2014/01/12/d5478cb8465 71c9d8e1844af240a75bb/kotova-ev-profilaktika-sindromaemotsionalnogo-vyigoraniya-uchebnoe-posobie.pdf.

2. Про деякі аспекти організації робочого часу : Директива 2003/88/ЄС Європейського Парламенту і Ради від 04.11.2003 р. [Електронний ресурс] // Офіційний вісник Європейського Союзу. - 2003. - С. L 299/9-L 299/19. - Режим доступу : http://ipzn.org.ua/wp-content/ uploads/2015/10/Dyrektyva-2003.88.YES.pdf.

3 . Action collaborative on clinician well-being and resilience [Electronic resource] / National Academy of Medicine. - 2017. - Access mode : http://nam.edu/ initiatives/clinician -resilience-and-well-being.

4. Burnout and satisfaction with work-life balance among US physicians relative to the general US population / T. D. Shanafelt, S. Boone, L. Tan [et al.] // Archives of Internal Medicine. - 2012. - Vol. 172. - P. 1377-1385.

\section{References}

1. Kotova, E.V. (2013). Profilaktika sindroma emotsionalnogo vygoraniya [Prevention of burnout syndrome]. Krasnoyarsk. Retrieved from: http://www.kspu.ru/upload/ documents/2014/01/12/d5478cb846571c9d8e1844af240 a75bb/kotova-ev-profilaktika-sindroma-emotsionalnogovyigoraniya-uchebnoe-posobie.pdf [in Russian].

2. (2003). Dyrektyva 2003/88/ES Yevropeiskoho parlamentu i rady vid 4 lystopada 2003 roku [Directive 2003/88/ES of the European Parliament and Council of November 4 2003]. Ofitsiinyi visnyk yevropeiskoho soiuzu - Official Bulletin of the European Union, L 299/9- L 299/19 [in Ukrainian].

3. National Academy of Medicine. (2017). Action collaborative on clinician well-being and resilience. Retrieved from: http://nam.edu/initiatives/clinician -resilience-andwell-being.

4. Shanafelt, T.D., Boone S., Tan L., Dyrbye, L.N., Sotile, W., Satele, D. et al. (2012). Burnout and satisfaction with work-life balance among US physicians relative to the general US population. Archives of Internal Medicine, 172, 1377-1385. doi: 10.1001/archinternmed.2012.3199. чоловіків з більшим стажем роботи $(\mathrm{p}=0,01)$, що може казати про більшу амбіційність та цілеспрямованість лікарів-інтернів.

6. У практичну та теоретичну роботу лікарів необхідно вводити тренінги, що мали б на меті покращити психологічний стан лікарів та допомагали здолати або зменшити емоційне вигорання.

5. Casey P. Our doctors are not immune to burnout and depression [Electronic resource] / P. Casey // Life Health \& Wellbeing. - 2016. - Access mode : https://www. independent.ie/life/health-wellbeing/our-doctors-are-notimmune-to-burnout-and-depression-34387680.html.

6. Hayes B. The national study of wellbeing of hospital doctors in Ireland [Electronic resource] / B. Hayes, L. Prihodova // Royal college of physicians of Ireland. - Access mode : https://www.rcpi.ie/research/hospitaldoctors-wellbeing/.

7. Interventions to prevent and reduce physician burnout: a systematic review and meta-analysis / C. P. West, L. N. Dyrbye, P. J. Erwin, T. D. Shanafelt // Lancet. - 2016. Vol. 388. - P. 2272-2281.

8. Shanafelt T. D. Addressing physician burnout: the way forward / T. D. Shanafelt, L. N. Dyrbye, C. P. West // The Journal of the American Medical Association. - 2017. Vol. 317. - P. 901-902.

5. Casey, Patricia. (2016). Our doctors are not immune to burnout and depression. Life Health \& Wellbeing. Retrieved from: https://www.independent.ie/life/healthwellbeing/our-doctors-are-not-immune-to-burnout-anddepression-34387680.html.

6. Hayes, Blanaid, \& Prihodova, Lucia. (2014). The national study of wellbeing of hospital doctors in Ireland. Retrieved from: https://www.rcpi.ie/research/hospital-doctors-wellbeing/.

7. West, C.P., Dyrbye, L.N., Erwin, P.J., \& Shanafelt, T.D. (2016). Interventions to prevent and reduce physician burnout: a systematic review and meta-analysis. Lancet, 388, 2272-2281. doi: 10.1016/S0140-6736(16)31279-X.

8. Shanafelt, T.D., Dyrbye L.N., \& West, C.P. (2017). Addressing physician burnout: the way forward. The Journal of the American Medical Association, 317, 901-902. doi: 10.1001/jama.2017.0076. 